\title{
Value Addition in Cassava Processing: Evidence from Women in Ilesa West Local Government Area of Osun State
}

\author{
E.O. Okebiorun ${ }^{1} \nless(1)$ \\ N.A. Jatto ${ }^{2}$ \\ "Department of Agric. Economics, Faculty of Agriculture, Usmanu Danfodiyo University, Sokoto, Sokoto State, \\ Nigeria
}

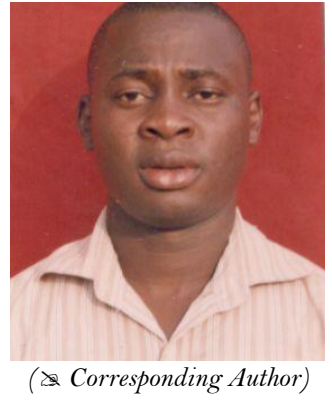

( Corresponding Author)

\begin{abstract}
To develop policies in addressing women problem in respect of their participation in cassava processing, the determinants and the level of their interest have to be adequately explored and understood. The study examined value addition to cassava in term of net return and factors influencing women interest in cassava processing in Ilesa West Local Government Area in Osun State. A purposive sampling technique was used to select 4 wards and 40 respondents were randomly selected within the L.G.A. using a structured questionnaire. The result shows that rate of investment on cassava processing was $\$ 0.39$ indicated that for every $\$ 1$ spend on cassava processing; 0.39 will be realized as profit. It is evident from the study that cassava processing is a profitable agricultural activity in the study area. The socioeconomic variables such as age, years of experience, income and membership in cooperative society contributed significantly to women interest in cassava processing in the study area. Years of experience and income are the main socio factor responsible for their interest in cassava processing. The major constraints to cassava processing in the area are heat from firewood. It is recommended that government through its research agencies should make available and affordable improved processing technology that is simpler to use for cassava processing more accessible.
\end{abstract}

Keywords: Value addition, Cassava processing, Evidence, Women interest, Ilesa West.

\section{Contents}

1. Introduction

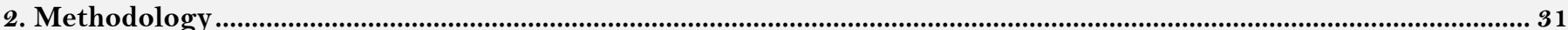

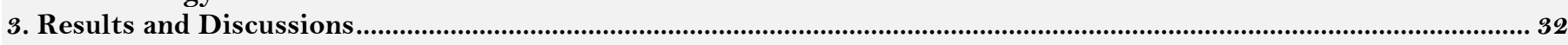

4. Conclusion and Recommendation ..15

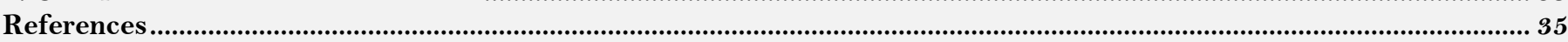

Citation | E.O. Okebiorun; N.A. Jatto (2017). Value Addition in Cassava Processing: Evidence from Women in Ilesa West Local Government Area of Osun State. Agriculture and Food Sciences Research, 4(1): 30-36.

History:

Received: 30 October 2015

Revised: 20 September 2017

Accepted: 27 September 2017

Accepted: 27 September 2017

Published: 2 October 2017

Licensed: This work is licensed under a Creative Commons

Attribution 3.0 License $(\mathrm{cc})$

Publisher:Asian Online Journal Publishing Group
Contribution/Acknowledgement: All authors contributed to the conception and design of the study.

Funding: This study received no specific financial support

Competing Interests: The authors declare that they have no conflict of interests.

Transparency: The authors confirm that the manuscript is an honest, accurate, and transparent account of the study was reported; that no vital features of the study have been omitted; and that any discrepancies from the study as planned have been explained.

Ethical: This study follows all ethical practices during writing. 


\section{Introduction}

Women form the majority of rural areas and are responsible for about $80 \%$ of all food items produced [1]. When focusing on agriculture as an economic activity the role of women cannot be undervalued as they account for $49.6 \%$ percent of Nigeria population [2]. Even though women play a dominant role in agriculture, they are hardly trained and reached by extension agents with improved technologies [3]. Many women believe that the agricultural industry is mostly for men.

However, what most women do not realize is that the percentage of women in the agricultural industry continues to increase almost every day [4] cited in Jatto, et al. [5]. Along with raising children and tending to duties inside the home such as cooking and laundry, women also tend to chores outside. Some duties include feeding animals, scooping manure and driving grain truck, these jobs are no longer seen only for man [2].

Jatto, et al. [2] also suggested that women's contribution to farm work is as high as the total farm task performed. The contribution of women ranges from such tasks as land clearing, land tilling, planting, weeding, fertilizer application to harvesting, food processing, threshing, milling and marketing as well as management of livestock [6]. With these, most tasks are supposedly meant for man but the benefits gained by them are not commensurate to the hours women spend on it. Many women believed that agricultural industry is still for men only, making them entrenched in a vicious cycle of poverty that placed them at less advantage of income and resource empowerment [6].

The National Research Centre for Women in Agriculture (NRECWA) [7] stated in their 2003-2004 report that women are faced with health hazards and about 50\% comes from transplanting on farm activities, $50 \%$ in post harvest activities comes from threshing and 47\% in livestock management comes from shed cleaning, these may be the part of reason while women's participation in agriculture is impeded. Policy issues in the past failed to address the unpleasant and deploring conditions under which women in the country contribute to agriculture; this perception arises because there is limited knowledge among the policymakers about the numerous contributions of women to agriculture especially in the area of food production in the country.

Efforts to add value to crops such as cassava require more attention now than ever before if Nigeria's agricultural sector is to evolve. Aside from improving farmers' incomes, value addition is one of the best ways to address the increasing level of unemployment in Nigeria International Institute of Tropical Agriculture [8]. Abubakar [9] reported that value addition to cassava would help turn around the fortunes of farmers and it offers tremendous opportunities that would further broaden the country's economic viability and improve its competitiveness particularly in the nonoil sector. Cassava is a major source of energy with very high food security value similar to most cereal crops $[10,11]$. Cassava possesses special attributes, which include ability to make returns of root yield even at extreme stress conditions; tolerance to unfavorable conditions like low soil PH, marginal soil fertility, and drought; suitability to various farming and food systems in Africa, minimal external input requirements, all year round availability as well as efficient production food energy. These attributes single cassava out as ideal crop for the tropics [12,13].

Alternative uses of cassava through value addition has resulted in emergence of wide food recipes from cassava through processing which involves conversion of edible food into another form more acceptable or more convenient to the consumer. Some value added products from cassava include Cassava flour, Cassava starch, Cassava bread, Cassava chin-chin, Cassava chips, Cassava flakes, Cassava odorless fufu, Cassava doughnut, Cassava cake, Cassava biscuit and Cassava salad cream. The value addition technology in cassava possesses enormous potentiality for increasing cassava consumption, diversifying its uses as well as using same to enhance livelihoods of farm families through providing opportunities for employment; micro agro enterprises development income and boosting economy of rural households [14]. In other to address women problems in respect of their participation in Agricultural processing activities most especially cassava processing and their level of interest have to be properly understood. Toward this end a study has been conducted to identify the value addition and factors influencing women to participate in cassava processing Ilesa West Local Government Area in Osun State.

\section{Methodology}

The research was carried out in Ilesha West Local Government Area in Osun State. The area lies between latitudes $7^{\circ} 39^{\prime} \mathrm{N}$ and $7^{\circ} 617^{\prime} \mathrm{N}$ and longitudes $4^{\circ} 43^{\prime} \mathrm{E}$ and $7^{\circ} 767^{\prime} \mathrm{E}$. It covers an estimated landmass of about 75 square kilometers with rivers like Adeti, Oora and Oromu traversing the Local Government Area. Its headquarters is located at Ereja Square (now at Omi-Aladiye, Osogbo Road) and is purely an urban area. The square is the headquarters of Ijesa division. The Local Government Area is unique in Ijesa land as its headquarters is the seat of Owa-Obokun Adimula, the paramount ruler of Ijesa land. The area was carved out of the old Ilesa Local Government Area, which was split into two in November 1996. The population of the inhabitant of the area as projected from the provisional figures of the 2006 National Population Census by 2014 is 137,495 peoples.

The annual mean temperature is about $85^{\circ} \mathrm{F}\left(29.44^{\circ} \mathrm{C}\right)$ and annual mean rainfall measures about 60 inches $(1,524 \mathrm{~mm})$. The area interspersed with hills within the ranges of 800 to 950 feet above sea level and it is relatively plain in contradistinction to the neighboring Ilesa East Local Government Area. Majority of the inhabitants in the area are farmers; this is due to the rich soil which support agricultural activities especially crop production (Cassava, Maize, Soybeans, Potatoes, Cotton, etc.) and a handful of them are engaged in cash and food crop production, they also involved in livestock farming (Poultry, Cattle, Sheep and Goat, etc.).

Four wards were purposively selected from Ilesa West Local Government Area of Osun State due to large population of cassava processor and 40 cassava processors (Women) were randomly selected from the four wards at random.

Primary data was collected for the study, using a structured questionnaire, containing information on the socio-economic characteristic of cassava processors, value addition to cassava in term of net return by the cassava processors and constraint faced by the cassava processors. The analytical tools used to analyze the data generated from the study descriptive statistic and a binary logit regression to assess the factors that influenced women participation n cassava processing. 


\subsection{Budgetary Techniques}

This is to estimate cost and return of the cassava processing and to determine value added to cassava in term of net return. Net return is the amount of money realized in a business after removing the cost involved in the business.

This can therefore be stated mathematically as:

$\mathrm{NR}=$ TR- TVC

Where: $\mathrm{NR}=$ Net return at each level of actor along cassava value chain. (Month)

$\mathrm{TR}=$ Total revenue at each level of actor along cassava value chain. (Month)

$\mathrm{TVC}=$ Total variable cost at each level of actor along cassava value chain. (Month)

ROI $=\frac{G-C}{C}$

Where: ROI = Rate of investment $($ Month)

$\mathrm{G}=$ Gain from production (Month)

$\mathrm{C}=$ Cost of production (Month)

\subsection{Binary Logit Model Specification}

Where,

$$
\frac{1}{X \mathrm{ij}}, J=1-8=F(Z i)=\frac{1}{1+e^{z i}}=\frac{e^{z i}}{e^{z i}+1} ; i=1-n
$$

$$
Z i=\alpha+\beta 1 X i 1+\beta 2 X i 2+\cdots+\beta 8 X i 8+U
$$

$1=$ women interested in cassava processing

$\mathrm{O}=$ not interested in cassava processing

$\mathrm{i}=$ Number of women sampled

$\mathrm{j}=1-8$ are the socio economic characteristic of women interested defined as:

$\mathrm{X}_{1}=$ processing experience (yrs.)

$\mathrm{X}_{2}=$ Education (yrs.)

$\mathrm{X} 3$ = amount of cassava processed $(\mathrm{kg} /$ month $)$

$\mathrm{X} 4=$ Age (yrs.)

$\mathrm{X} 5=$ Income $(\mathrm{N})$

$\mathrm{X} 6=$ Dependency ratio

$\mathrm{X} 7=$ Children (number)

$\mathrm{X} 8=$ Participation in cooperative society (years)

$\beta 1-\beta 8=$ Logit coefficient

$\alpha=$ Constant term.

$\mathrm{U}=$ error term which will be assumed to be normally distributed with zero mean and constant.

\section{Results and Discussions}

The responses of the cassava actors in Ilesa West Local Government Area were analyzed using descriptive statistic. The results on socio-economic characteristic of the cassava processors are presented in Table 1. The socio-economic characteristics of cassava processors have direct or indirect influence on cassava processing. The variables identified under this include; age, marital status, family size, level of education, year of experience and the main occupations of the cassava processors.

Table-1. Distribution of the cassava processors according to Age, Gender, Marital status and Family

\begin{tabular}{l|l|l|l}
\hline status and Family & & Frequency & Percentage \\
\hline Age range (years) & & & \\
\hline$\leq 30$ & & 4 & 10 \\
\hline $31-40$ & & 3 & 7.5 \\
\hline $41-50$ & & 23 & 57.5 \\
\hline $51-60$ & & 7 & 17.5 \\
\hline$>60$ & & 3 & 7.5 \\
\hline Mean & $\mathbf{4 5 . 6}$ & & \\
\hline Marital status & & & 10 \\
\hline Single & & 4 & 37.5 \\
\hline Married & & 15 & 30 \\
\hline Divorced & & 12 & 22.5 \\
\hline Widowed & & 9 & \\
\hline Family size & & & 60 \\
\hline $1-5$ & & 24 & 37.5 \\
\hline $6-10$ & & 15 & 2.5 \\
\hline $11-15$ & & 1 &
\end{tabular}

The socio-economic characteristics of cassava farmers have direct or indirect influence on resources use efficiency in cassava production and are presented in Table 1. The age of the respondents determine the effort and quality of labour he/she employs in any given area [15]. The results show that majority, $65 \%$ of the cassava processors were between the age group of $31-50$ years old. This indicated that most of the cassava processors are in their active age years. This implies that most of the actors involved are likely to be physically fit to perform cassava processors activities. The mean age of cassava actors was 45.6 years. Rathman, et al. [16] shows that 47.96 years is within the economically active age and as such will respond positively to any intervention aimed at improving their productive capacity. 
Marital status determines the family size of the cassava processors and consequently determines the number of people expected to work in processing activities. The marital status of cassava processors is presented in Table 1. The result reveals that majority of the cassava farmers $(37.5 \%)$ are married while $30 \%$ are divorced. This result agrees with the work of Ofuoku [17] and Fakoya, et al. [18] who noted that married people have the responsibilities of catering for the needs of their families and also engage in various economic activities that would serve as source of income.

The household size of cassava farmers determines the contribution of the family members in cassava processing. This determines the number of family members in a household that could contribute to family labour. Table 1 reveals that majority of the farmers (60\%) have family sizes ranging from 1 to 5 individuals. The result of this finding is in line with the result of Igodan, et al. [19] who reported that educated farmers tend to have smaller families. Arthur [20] also observed that small family size enjoy better economic and social lives, which have great influence on better understanding of environmental conditions but reduced labour availability.

Table-2. Distribution of cassava processors according to education status, source of capital, occupation and year of experience

\begin{tabular}{l|l|l}
\hline & Frequency & Percentage \\
\hline Education status & & \\
\hline No Formal & 8 & 20 \\
\hline Primary & 19 & 47.5 \\
\hline Secondary & 10 & 25 \\
\hline Tertiary & 1 & 2.5 \\
\hline Islamic & 1 & 2.5 \\
\hline Adult Education & 1 & 2.5 \\
\hline Source of capital & & \\
\hline Personal saving & 21 & 52.5 \\
\hline Friend \& relative & 12 & 30 \\
\hline Money lender & 5 & 12.5 \\
\hline Bank & 2 & 5 \\
\hline Occupation & & \\
\hline Primary & 36 & 90 \\
\hline Secondary & 4 & 10 \\
\hline Year of experience & 3 & \\
\hline $1-10$ & 3 & 7.5 \\
\hline $11-20$ & 17 & 42.5 \\
\hline $21-30$ & 12 & 30 \\
\hline$>30$ & 8 & 20
\end{tabular}

Education plays a vital role in adoption of innovative practices among the cassava processors. Education is seen as a means of acquiring knowledge on new technology being practiced to add value and increase efficiency. With high level of education, adoption of new technology becomes easy. Table 2 revealed that $47.5 \%$ of the cassava processors have attained and obtained primary school certificate, while $25 \%$ attended secondary school. It was observed that farmers with primary and secondary school education dominated the cassava production activities. Williams [21] and Adesoji and Farinde [22] noted that secondary education could equip farmers with some managerial skills in agri-business and help in understanding innovations.

Capital is one of the factors of production, without which the production will not be possible. The importance of capital in production is much particularly as related to smallholder farmers, as most farmers had little or no money to carry out important farm operations or purchase modern yield exchanging input in production at the required. Capital also is important because it help the farmers to expand their activities. Sources of capital of cassava processors are presented in Table the result shows that $52.5 \%$ of processors source their capital from their personal savings to finance their activities, while $30 \%$ source their capital from friends and relatives. This result indicated that cassava processors do not have much access to capital from banks in the study area. The result agrees with that of Alimi [23] who observed that food crop farmer's major source of capital (working capital) was personal saving which was inadequate.

Occupation involves activity that is carried out by an individual to derive a certain benefit or to enable the individual sustains a living. The distribution of the cassava processors based on occupation is shown in Table 2 . The Table shows that $90 \%$ of cassava processors consider their engagement into cassava processing activities as primary occupation while the remaining $10 \%$ involved in secondary occupation in casa of failure in one activity, they will easily change to the other.

Years of experience of the cassava processors, this refers to the number of years over which the cassava processors have been engaged in cassava processing activities. The more experienced one has, the higher the profit margin. Also, the more the period a farmer spends in the practice, the more he/she will improve in managerial capability and overall efficiency. The results of the cassava processors based on the years of experience are represented in the Table 2 . The result indicates that most of the cassava processors $(92.5 \%)$ have not less than 11 years of experience in their engagement into cassava processing activities. It is expected that the processors are aware of new processing technology, and this would likely help the processors in achieving higher level of productivity. 


\subsection{Cost and Returns Structure of the Cassava Processors}

Table-3. Average Cost and Returns Structure of the Cassava Processors / Month

\begin{tabular}{l|l|l}
\hline Item & Amount & Percentage \\
\hline Quantity of cassava purchased (bag) & 71.80 & \\
\hline Unite price of cassava (N/bag) & $1,139.00$ & \\
\hline Total value of cassava purchased (N) & $81,780.20$ & 66.55 \\
\hline Unit cost of processing (N/bag) & 572.50 & \\
\hline Total cost of processing (N) & $41,105.50$ & 33.45 \\
\hline Total variable cost (N) & $122,885.70$ & 100 \\
\hline Unit price of cassava output (N/bag) & 2,372 & \\
\hline Total returns ( $)$ & $170,309.60$ & \\
\hline Net returns $(\mathbf{N})$ & $\mathbf{4 7 , 4 2 3 . 9}$ & \\
\hline Net returns as a \% of cost incurred & $\mathbf{3 8 . 5 9}$ & \\
\hline R O I (N) & $\mathbf{0 . 3 9}$ & \\
\hline Source Field survey 014 & &
\end{tabular}

Source: Field survey, 2014

Cost and returns structure of the cassava processors is presented in Table 3. It can be observed that an average cassava processor utilized 71.8 bags of cassava per month in their processing activities. Out of the total cost incurred by an average cassava processor per month, the greatest share $(66.55 \%)$ was spent on the purchase of raw cassava and the remaining $33.45 \%$ was incurred as the cost of processing the cassava. An average cassava processor realizes a net return of $\$ 7,423.90$ per month represent $38.59 \%$ of the total cost incurred per month. Further analysis on rate of investment on cassava processing showed that for every 1 invested into cassava processing, \#.39 is realized as profit. This implies that cassava is a lucrative enterprise.

\subsection{Constraints Faced by Cassava Processors}

Table-4. Constraints Faced by Cassava Processors

\begin{tabular}{l|l|l}
\multicolumn{2}{c}{ Table-4. Constraints Faced by Cassava Processors } \\
\hline Problems & Frequency & Percentage \\
\hline High cost of cassava & 25 & 62.5 \\
\hline Drainage problem & 32 & 80 \\
\hline Hazard faced & 20 & 50 \\
\hline Scarcity of firewood & 29 & 72.5 \\
\hline Low demand for gari in the market & 21 & 52.5 \\
\hline Shortage of laborers & 18 & 45 \\
\hline $\begin{array}{l}\text { Note: * Multiple responses. } \\
\text { Source: Field survey, 2014. }\end{array}$ &
\end{tabular}

The constraints in cassava processing in the study area were found to be numerous, stating from high cost of cassava, water lodge, heat from firewood and scarcity of firewood, Table 4 shows the gravity of these constraints provided by cassava processors. These constraints reported by the cassava producers are critical. The Table shows that $80 \%$ of cassava processors encounter drainage problems as a result of poorly drained topographically and $72.5 \%$ of them find it difficult to get enough wood in preparing their product while $62.5 \%$ of them are being faced with the problem of high cost of cassava. The results are in line with Abdulkarim, et al. [24] who argued that water logging and erosion are one of the factors affecting cassava-processing activities.

Table 4 shows the distribution of Maximum likelihood estimate women interest in cassava processing in Ilesa west local government. The table shows that number of children, dependency ratio and years spent on education are not significant, but age and membership in cooperative society had a significant negative coefficient but significant while years of experience and income had a positive coefficient and significant. It is being noted that a positive sign on a parameter indicated that higher values of variables tends to increase the likelihood of women processors in cassava production. Similarly, a negative value of coefficient implied that higher values of the variables would reduce the probability women interest in cassava production.

Table-5. Maximum likelihood estimate women interest in cassava processing in Ilesa west local government

\begin{tabular}{l|l|l|l}
\hline Variables & Coefficients & Std. error & P-value \\
\hline Constant & 25.8584 & 9.15772 & $0.00475^{* * *}$ \\
\hline Age & -0.424411 & 0.157892 & $0.00719^{* * *}$ \\
\hline Number of Children & 0.228914 & 0.346629 & 0.50900 \\
\hline Dependent ratio & -0.830329 & 1.08079 & 0.44233 \\
\hline Years of education & 0.264233 & 0.208643 & 0.20537 \\
\hline Years of experience & 0.383089 & 0.166958 & $0.02176^{* *}$ \\
\hline Income & 0.0000036 & 0.00000166 & $0.03045^{* *}$ \\
\hline Membership in cooperative society & -6.03709 & 2.07297 & $0.00359^{* * *}$ \\
\hline Mean dependent variable & 0.50000 & & \\
\hline Log-likelihood & -13.02386 & &
\end{tabular}

The result indicates that age, years of experience; income and membership in cooperative society might influence women interest in cassava processing. The variables age and membership in cooperative society had a negative coefficient and significant at $1 \%$, while years of experience and income have a positive coefficient which are significant at 5\% level. Considering years of experience and income it might imply that for every one year experience gained might increase the probability to participation in cassava processing. This could be because they 
are likely to be more sensitive to risk in their decisions and actions that may affect their productivity and might imply also that a woman cassava processor whose income has increased is due to her experience in the processing activities this is also supported by Jatto, et al. [5]. While for every one-year increase in age and membership in cooperative society may decrease the likelihood of women participation in cassava processing.

The log-likelihood (-13.02346) indicate that there is no close relationship within the variables and the omnibus test of the model which gives the overall fit test indicate a chi-square value of 84.8566 which is significant $(\mathrm{p}<0.01)$ implies that the model as a whole fit significantly better.

The predicted marginal probability of women interest in cassava processing as related to the significant socioeconomic variable is shown in Table 5 . The Table showed that age and membership in cooperative society have a negative marginal probability. Income and years of experience shows a positive marginal probability

Table-6. Marginal effect of binary logit regression

\begin{tabular}{l|l|l|l}
\hline Variables & Coefficient & Std. error & Marginal effect \\
\hline Constant & 24.1543 & 9.09713 & - \\
\hline Age & -0.392912 & 0.157012 & -0.053984 \\
\hline Years of experience & 0.28416 & 0.107409 & 0.0390421 \\
\hline Income & 0.00000226 & 0.00000163 & 0.000000311 \\
\hline Membership in cooperative society & -4.47877 & 1.29146 & -0.615358 \\
\hline
\end{tabular}

Source: Field survey, 2014

The result shows that age and membership in cooperative society may not necessary be a factor contributing to women interest in cassava processing meaning that they may not be educated and may not belong to any cooperative society to be a cassava processor. Years of experience have the highest extent of influence to which a unit change increases the probability of the women interest in cassava processing. The implication is that it increases the likelihood of more access to income.

\section{Conclusion and Recommendation}

It is evident from the study that, cassava processors in the study area showed that cassava processing is profitable agricultural activity in the study area and majority of them having not less than 11 years of experience. The socioeconomic variables such as age, years of experience, income and membership in cooperative society contributed significantly to women interest in cassava processing in Ilesa west local government area of Osun state. Years of experience and income are the main socio factor responsible for their participation in cassava processing. The major constraints to cassava processing in the area are heat from firewood. It is recommended that government through its research agencies should make available and affordable improved processing technology that are simpler to use and also make cassava processing more accessible.

\section{References}

[1] D. O. Awotide, "Assessment of women's participation in cooperative societies and its determinants in Yewa North local government area of Ogun State, Nigeria Asian," Journal of Agriculture and Rural Development, vol. 2, pp. 344-350, 2012. View at Google governmer
Scholar

[2] N. A. Jatto, U. I. Gunu, and A. Alkali, "Determining Women Interest in poultry egg farming in Ilorin, Kwara State," International Journal of Current Research, vol. 5, pp. 065-067, 2013.

[3] S. A. Rahman and J. F. Alamu, "Estimating the level of women Interest in agriculture: An application of logit regression model," Nigerian Journal of Scientific Research, vol. 4, pp. 45-49, 2003. View at Google Scholar

B. Kirk, Women Participation in Agriculture: Lecture Delivered at Southern Illinois University, 2012.

M. A. Damisa, R. Samadi, and M. Yohanna, "Women participation in agricultural production: A probit analysis," Journal of Applied Sciences, vol. 7, pp. 412-416, 2007. View at Google Scholar $\mid$ View at Publisher

[6] National Research Centre for Women in Agriculture (NRECWA), Women participation in agriculture. Orissa, India: Indian Council of Agriculture Research, 2004.

[7] International Institute of Tropical Agriculture, "Competitiveness Workshop," presented at the In Opportunities for Cassava Production in Nigeria: Bokanga, IITA, Ibadan, 2011.

[8] A. Abubakar, "Employment creation and opportunities in the agro-allied sub-sector- the case of cassava production," Central Bank of Nigeria Bullion, vol. 24, pp. 1-10, 2003.

[9] E. B. Oguntona, "Need for consistency in Nigerian agricultural development policy: Agricultural development in Nigeria," Obafemi Awolowo University Press Ile Ife, vol. 1, pp. 35-70, 1999.

[10] S. C. Achinewhu and C. I. Onwuama, "Garification of five improved cassava cultivars in Nigeria and physicochemical and sensory properties of gari yield," African Journal of Root and Tuber Crops, vol. 4, pp. 95-111, 2000.

[11] J. R. Beeching, T. Niger, and J. Tohme, "Post-harvest physiological deterioration of cassava," in Proceedings of 12th Symposiums of International Society of Tropical Root Crop held in Tsuba, Japan September, 10-16, 2000.

[12] E. T. Awah and A. Tumanteh, "Cassava based cropping systems and use of Inputs in different econological zone of central Africa," Africa Journal of Root and Tuber Crops, vol. 4, pp. 20-27, 2001. View at Google Scholar

[13] F. N. Nwakor, K. C. Ekwe, L. E. Amamgbo, H. N. Anyaegbunam, L. Ironkwe, and G. N. Asumugha, Annual Report of NRCRI, Umudike, Imo State2007.

[14] R. A. Alkali, Issues in international relations and Nigeria's foreign policies, 2nd ed. Kaduna: North Point Publishers, 2003.

[15] S. A. Rathman, A. O. Ogungbile, and R. Tabor, "Factors affecting adoption of CSVV111 and ICSV400 sorghum variety in Guinea and Sudan of Nigeria," Journal of Crop Research Agro-Forestry and Environment, vol. 1, pp. 21-35, 2002. View at Google Scholar

[16] A. U. Ofuoku, "The role of community development committees in farmers-herder conflict in central agricultural zone of delta State, Nigeria," International Journal of Rural Studies, vol. 16, pp. 1-10, 2009. View at Google Scholar

[17] E. O. Fakoya, T. O. A. Banmek, O. R. Ashinmolowo, and O. E. Fapojuwo, "Cassava production and poverty eradication among crop farmers in Ondo State, Nigeria," International Journal of Sustainable Development, vol. 2, pp. 65-72, 2010. View at Google Scholar

[18] C. O. Igodan, P. E. Ohaji, and J. A. Ekpere, "Factors associated with the adoption of recommended practices for Maize Production in Kanji Lake Basin of Nigeria," Agricultural Administration and Extension, vol. 29, pp. 149-156, 1988. View at Google Scholar $\mid$ View at Publisher

[19] J. Arthur, "Family size and quality of life Nexus: A case of the sunyani municipality, Ghana," presented at the 5th African Population Conference, Arusha, Tanzania, 10th - 14th December 2007, 2006.

[20] C. E. Williams, Reaching the Africa female farmer with innovative extension approaches. In Steven A. B. (Eds.), Women, agriculture household and food security. Mexico City, Mexico: Sasakawa Africa Association, 1997.

[21] S. A. Adesoji and A. J. Farinde, "Socio economic factors influencing yield of arable crop in Osun State, Nigeria," Asian Journal of Plant Sciences, vol. 5, pp. 630-634, 2006. View at Google Scholar | View at Publisher 
[22] T. Alimi, "Application of markov chain analysis in forecasting arable crop farm size," Nigeria Journal Basic Apply Science, vol. 8, pp. 27-36, 1999. View at Google Scholar

[23] B. Abdulkarim, D. A. Ibrahim, O. Omotoso, A. G. Shehu, and I. Ukin, "Report on survey of selected agricultural raw material in Nigeria on maize," presented at the Published by Raw Materials Research and Development Council, Federal Ministry of Science and Technology. Garki, Abuja, Nigeria, 2004.

[24] N. A. Jatto, M. A. Maikasuwa, U. B. Kyiogwom, and I. Muhammad, "Evaluating the factors influencing poultry farmers' participation in egg production: A binary logit regression model," European Scientific Journal, vol. 8, pp. 125-134, 2012. View at Google Scholar 